\title{
ЗДРАВООХРАНЕНИЕ КУБАНИ И СТАВРОПОЛЬЯ В ПЕРИОД \\ НЕМЕЦКО-ФАШИСТКОЙ ОККУПАЦИИ (1942-1943 гг.): \\ ПРОБЛЕМЫ ИСТОЧНИКОВЕДЕНИЯ
}

В статье рассматриваются вопросы, связанные с изучением источников информации о функционировании системы здравоохранения Краснодарского и Ставропольского краев в период немецко-фашистской оккупации, продлившейся с июля 1942 по октябрь 1943 гг. Несмотря на большое количество различных материалов о пребывании оккупантов на территории Кубани и Ставрополья, ряд важных аспектов, связанных с первоначальными планами германского командования в отношении местного населения, а также практической их реализацией, остаются малоизученными. Для оккупационных властей вопросы, связанные с охраной здоровья гражданского населения и оказанием ему медицинских услуг, не входили в число первостепенных, во многом их упоминание в документах периода оккупации имело идеологическую подоплеку и происходило исключительно в пропагандистских целях. Тем не менее, ряд материалов довольно наглядно демонстрирует наличие определенной системы мер, разработанной германскими властями и направленной как на обеспечение собственной безопасности, так и на поддержание в удовлетворительном состоянии здоровья местного населения, вовлекаемого в экономические отношения при «новом порядке», в том числе и в качестве рабочей силы. Изучение советских источников, в свою очередь, указывает на то, что на протяжении многих лет содержащаяся в них информация имела определенную окраску и в значительной степени описывала ущерб, нанесенный системе здравоохранения Кубани и Ставрополья в результате пребывания на их территории немецко-фашистских войск. Положительным моментом является существенный объем фактологических данных, содержащихся в этих источниках информации, первоначально зафиксированный комиссиями различных уровней и впоследствии вошедший в материалы Чрезвычайной государственной комиссии по установлению и расследованию злодеяний немецко-фашистских захватчиков и их сообщников и причиненного ими ущерба. Анализ различных источников информации должен способствовать изучению и объективному описанию политики оккупационных властей в области охраны здоровья жителей региона, работы медицинских учреждений, а также наиболее полному подведению итогов пребывания оккупантов на территории Краснодарского и Ставропольского краев.

Ключевые слова: Краснодарский край, Ставропольский край, Великая Отечественная война, оккупация, архив, газета, здравоохранение, медицина, профилактика заболеваний, холокост.

\section{HEALTH CARE IN THE KUBAN AND STAVROPOL REGIONS DURING THE GERMAN NAZI OCCUPATION (1942-1943): SOURCE STUDY PROBLEMS}

The article deals with issues related to the study of information sources on the functioning of the health system of Krasnodar and Stavropol regions during the Nazi occupation, which lasted from July 1942 to October 1943. Despite the large number of different materials about the stay of the occupants in the Kuban and Stavropol, a number of important aspects related to the original plans of the German command in relation to the local population, as well as their practical implementation, remain poorly studied. For the occupation authorities, issues related to the protection of the health of the civilian population and the provision of medical services to them were not among the priority issues, in many respects their mention in the documents of the occupation period had an ideological background and was exclusively for propaganda purposes. Nevertheless, a number of materials quite clearly demonstrates the existence of a certain system of measures developed by the German authorities and aimed at both ensuring their own safety and maintaining a satisfactory state of health of the local population involved in economic relations under the "new order", including as a labor force. The study of Soviet sources, in turn, indicates that for many years the information contained in them had a certain bias and largely described the damage caused to the health system of the Kuban and Stavropol due to the stay of the German fascist troops on their territory. On the positive side, there is a significant amount of factual data contained in these sources, originally recorded by commissions of various levels and subsequently included in the materials of the Extraordinary state Commission for the identification and investigation of the atrocities of the Nazi invaders and their accomplices and the damage caused by them. The analysis of various sources of information should contribute to the study and objective description of the policy of the occupation authorities in the field of health protection of residents of the region, the work of medical institutions, as well as the most complete summing up of the occupants' stay in the Krasnodar and Stavropol regions.

Key words: Krasnodar Krai, Stavropol Krai, Great Patriotic War, occupation, archive, newspaper, health care, medicine, disease prevention, Holocaust. 
Несмотря на наличие существенного количества опубликованных материалов, связанных с немецко-фрашистской оккупацией Северного Кавказа во время Великой Отечественной войны, вопросы функционирования системы здравоохранения Кубани и Ставрополья в указанный период времени можно отнести к разряду малоизученных. Целью настоящего исследования является изучение источниковой базы вопросов, связанных с политикой немецких властей в области здравоохранения, состоянием медицинского обслуживания населения, а также медико-санитарными последствиями пребывания оккупантов на территории Краснодарского и Ставропольского (до 12.01.1943 г. - Орджоникидзевского) краев.

Одним из основных видов источников для исторических исследований функционирования системы здравоохранения Кубани и Ставрополья в период оккупации являются архивные материалы, хранящиеся в фондах Государственного архива Российской Федерации (ГАРФ), Государственного архива новейшей истории Ставропольского края (ГАНИСК), Центра документации новейшей истории Краснодарского края (ЦДНИКК) Государственного архива Ставропольского края (ГАСК) и Государственного архива Краснодарского края (ГАКК).

Среди фондов ГАРФ необходимо в первую очередь выделить фонд 7445 («Нюрнбергский процесс над главными немецкими военными преступникамим), опись 2, дело 99, в котором в том числе хранятся материалы из канцелярии А. Розенберга. Согласно документам из так называемой «Кавказской папки», Розенберг убеждал Гитлера в необходимости проведения на Кавказе преобразований, имевших отличия от оккупационной политики в других захваченных регионах Советского Союза. Овладение Кавказом Розенберг во многом считал задачей политической при решении которой должна быть проявлена «большая гибкость в осуществлении интересов Германской империи и обеспечении ее будущего», а для поддержания порядка и проведения хозяйственных мероприятий по возможности использовать «ограниченное количество немцев и союзных кадров», привлекая к этому «местные, преданные Германии круги» [22].

В фонде 7021 ГАРФ хранится существенный объем документов Чрезвычайной государственной комиссии по установлению и расследованию злодеяний немецко-фашистских захватчиков и их сообщников и причиненного ими ущерба гражданам, колхозам, общественным организациям, государственным предприятиям и учреждениям СССР (ЧГК) по Краснодарскому [20] и Ставропольскому краям [21]. Дела фонда содержат акты, заявления, свидетельские показания, докладные записки и другие документы о зверствах, издевательствах, расстрелах и умерщвлениях людей, грабежах, проводимых немецко-фашистскими захватчиками и их сообщниками

В фондах ГАНИСК также хранятся материалы о злодеяниях оккупантов, в частности, по г. Ставрополю. Ряд документов непосредственно касается убытков, причиненных лечебно-профилактическим заведениям города - больницам, поликлиникам, диспансерам, детским и женским консультациям, родильному дому, аптекам, краевой противочумной и межрайонной эпидемической станции, некоторые документы касаются проводимой оккупантами политики [19]. Кроме того, в фондах архива хранится статистическая информация, в частности, о численности населения городов и районов края (с выделением трудоспособной части, с учетом эвакуированных) в предшествующий оккупации период времени [18].

В фондах ЦДНИКК хранится подшивка оккупационной газеты «Кубань», а также содержится информация о распространении советских газет на оккупированной территории Краснодарского края [67].

В делах фондов Р-1053 [23], Р-2498 [27] и Р-2569 [28] ГАСК, относящихся к периоду оккупации Ставропольского края, хранятся акты медицинских обследований, переписка и отчеты о работе Ставропольского городского отдела здравоохранения, приказы по личному составу и переписка главного врача г. Пятигорска, приказы и распоряжения Ессентукского городского и районного управления, а также сведения о работе Ставропольской городской больницы, психиатрической больницы, кожно-венерологического диспансера и ряда других учреждений. В отдельных делах фондов P-1059 [24] и Р-1121 [25] хранится документация немецкого командования (указания, распоряжения, переписка и др.) по организации хозяйственной деятельности и установлению «нового порядка» на территории края. Документы, касающиеся злодеяний немецко-фашистских захватчиков и их сообщников в различных районах Ставропольского края, хранятся в фонде P-1368 архива [26].

В фондах ГАКК необходимо выделить фонд P-418 (Управление Главного врача Краснодарской области) [8], содержащий приказы, отчеты - работе, переписку с районными врачами и руководством созданного новыми властями органа здравоохранения. Инорормация о работе в период оккупации отдельных подразделений системы здравоохранения, а также некоторых лечебных учреждений хранится в фондах Р-430 (Краснодарский дезинфекционный отряд) [9], Р-440 (Краснодарский туберкулезный диспансер) [10], P-477 (Краснодарский венерологический диспанcep) [11], Р-505 (Ейская городская больница) [12], P-584 (Краснодарская городская инфекционная больница) [13], Р-590 (Северский районный отдел здравоохранения) [14], Р-1255 (Анапская районная больница) [16]. Документация отдела здравоохранения исполнительного комитета Краснодарского краевого Совета депутатов трудящихся, которая позволяет оценить состояние системы здравоохранения в крае накануне оккупации, а также непосредственно после освобождения его территории, содержится в фонде Р-1393 [17]. Фонд Р-897 включает в себя документы Краснодарской краевой комиссии по установлению и расследова- 
нию злодеяний, совершенных немецко-фрашистскими захватчиками и их сообщниками [15]

Несмотря на существенный объем материалов, хранящихся в фредеральном и краевых архивах, следует отметить фрагментарность информации о функционировании системы здравоохранения на оккупированных территориях Кубани и Ставрополья. Одна часть документации вывозилась оккупантами при отступлении или целенаправленно уничтожалась, другая - могла быть утрачена или испорчена в условиях военного времени, а также в последующие десятилетия. Кроме того, необходимо учитывать, что документы в архивах зачастую структурированы таким образом, что поиск информации по изучаемому вопросу бывает затруднен. В этой связи следует отметить, что для объективного и наиболее полного раскрытия исследуемой проблемы необходимо использовать максимально широкий круг источников информации.

Появление первых источников, ставших основой для исторических исследований изучаемого вопроса, произошло непосредственно во время пребывания захватчиков на территории региона. К таким источникам, в первую очередь, относится периодическая печать. Буквально с первых дней оккупации в издаваемых новыми властями местных газетах «Кубань» (г. Краснодар), «Майкопская жизнь» (г. Майкоп), «Новое время» (г. Кропоткин), «Вестник Кубани» (г. Армавир), «Возрождение Кубани» (г. Тихорецк), «Анапский вестник» (г. Анапа), «Русская правда», «Ставропольское слово», «Утро Кавказа», (г. Ставрополь, до 12.01.1943 г. Ворошиловск), «Кавказский вестник», «Пятигорское эхо» (г. Пятигорск), «Заря» (г. Ессентуки), «Прикумский вестник» (г. Буденновск), «Свободный Карачай» (г. Микоян-Шахар), «Новая жизнь» (г. Черкесск) [34, с. 25-26] и др. стали публиковаться различного рода материалы, носившие как информационно-новостной, так и нормативно-правовой характер.

Так, в оккупационной газете «Русская правда» был опубликован первый распорядительный документ новых властей в захваченном Ставрополе приказ о регистрации специалистов определенных профессий, в том числе врачей, фельдшеров и младшего медицинского персонала [57]. В этом же издании размещалась инсоормация о работе созданного оккупантами в структуре городской управы отдела здравоохранения, включавшего санитарный подотдел в составе двух санитарных врачей и одного специалиста по эпидемиологии [6], планах по возобновлению занятий с 01.09.1942 г. в Ставропольском медицинском институте [5], открытии детской поликлиники в Ставрополе [30].

Об открытии в г. Краснодаре 6 поликлиник, 4 детских консультаций, 2-й городской больницы на 255 коек и 3-й клинической больницы на 640 коек, родильного дома, 7 аптек, зубной поликлиники и малярийной станции отчитывались новые власти на страницах краснодарской газеты «Кубань» [44].
В газете «Ставропольское слово» была опубликована информация о выделении в сентябре 1942 г. городскому отделу здравоохранения 180 тыс. руб. из собранных в августе 1942 г 600 тыс. руб. доходов [47], а также о решении новых властей выплачивать рабочим и служащим заработную плату за время болезни, удостоверенной врачебными документами, в полном объеме, независимо от продолжительности работы на данном предприятии или в учреждении [53]

«Прикумский вестник» приводил данные о выделении управой г. Буденновска во втором полугодии 1942 г. на нужды здравоохранения 131 тыс. руб. или около $7 \%$ бюджета, что было втрое больше, чем выделялось по указанной статье горисполкомом Буденновска в 1941 г. [42, с. 278]

В газетах публиковались приказы новых властей об обеспечении санитарного состояния населенных пунктов, в которых регламентировались правила содержания жилого и нежилого фондов порядок уборки и очистки улиц, оборудования мусорных ящиков, организации свалок мусора и т.д. $[55,56]$. На страницах периодических изданий, выходивших в краевых центрах, оккупанты сообщали о мероприятиях в области здравоохранения, проводимых ими на уровне районов. Краснодарский краевой отдел здравоохранения отчитывался о работе районных больниц, комплектовании штатов врачебных лечебных участков, открытии фельдшерско-акушерских пунктов [3]. Издание "Утро Кавказа» сообщало о назначении районных врачей в 16 прилегающих к г. Ставрополю районах, работе печебных учреждений, санитарном и эпидемиологическом состоянии в них [37]. Там же размещалась информация о принятии германским командованием «энергичных мер для восстановления лечебной деятельности Пятигорского курорта», возобновлении работы бальнеологического института, открытии химико-фармацевтического института на 500 учащихся [35].

В первом номере газеты за 1943 г. заведующий медицинским отделом г. Ставрополя М. Ю. Шульц отчитывался о работе, проделанной за 5 месяцев в краевом центре и 16 ближайших к нему районах, отметив проведение ряда профилактических мероприятий по борьбе с малярией, оспой, дифтерией [36]. Ряд материалов в периодической печати был посвящен разъяснению ситуации с взиманием платы за оказание медицинских услуг [66], а также за санитарный осмотр открывающихся предприятий, ларьков, столовых, бань и т.д. [7]. Кроме того, в газетах периода оккупации регулярно размещалась информация о проведении различными учреждениями на возмездной основе всевозможных анализов (фармацевтических, токсикологических, судебно-медицинских, технических и др.) [49], а также печатались объявления частнопрактикующих врачей об оказании ими услуг населению [50].

Следует отметить, что в целом данный вид исторических источников выполнял функции формирования необходимого для оккупационных властей общественного мнения и идеологическо- 
го воздействия на население, играл определенную роль в системе управления и содействовал экономическому развитию оккупированных территорий Содержащаяся в данных источниках и имеющая безусловную ценность информация предполагает тем не менее, критическое к себе отношение и во многих случаях требует перепроверки.

Существенный объем сведений по рассматриваемой проблематике содержится и в советских периодических изданиях, размещавших, как правило, материалы об ущербе, причиненном оккупантами медицинским учреждениям и здоровью местных жителей, санитарном состоянии населенных пунктов к моменту их освобождения Красной Армией и другие данные. Так, в газете «Ставропольская правда», рассказывавшей о проведенном в освобожденном Ставрополе совещании медицинских работников, отмечалось уничтожение захватчиками при отступлении из города поликлиники, родильного дома, нескольких детских яслей, разорение психиатрической больницы и тубдиспансера, ликвидация детской больницы. Участники совещания, указывая на повышение оккупантами цен на медикаменты и введение платы за медицинские услуги, констатировали практически полное лишение населения лечебной помощи, а также приведение города в антисанитарное состояние [54].

Краснодарская краевая газета «Большевик», редакция которой в период оккупации находилась в г. Сочи, неоднократно публиковала материалы о пребывании захватчиков на Кубани, в том числе касающиеся и рассматриваемой проблематики $[29,51,68]$. Подробности судебного процесса по делу о зверствах немецко-фашистских захватчиков и их пособников на территории г. Краснодара и Краснодарского края в период оккупации публиковались в июле 1943 г. как в местных газетах «Под знаменем Ленина», «За коммуну», «Адлеровская правда», «Большевик» [39, 59], так и в общесоюзных изданиях «Комсомольская правда» [64] и «Красная Звезда» [2]. При рассмотрении размещенной в советских периодических источниках информации необходимо учитывать, что, несмотря на ее правдивый по своей сути характер, публикация происходила в условиях продолжающейся борьбы с врагом и носила определенную идеологическую окраску.

Важным источником исследования изучаемой проблемы стали сообщения и акты ЧГК, основой которых является большое количество актов подведомственных (в первую очередь - Краснодарской краевой и Ставропольской краевой) комиссий, протоколов опросов свидетелей и заявлений о преступной деятельности оккупантов, которые послужили одними из главных доказательств обвинения как на судебном процессе в г. Краснодаре в июле 1943 г., так и на последующих судебных процессах. Анализ документов ЧГК помогает понять замыслы оккупантов в отношении медицинского обслуживания местного населения, а также восстановить картину их преступлений на Кубани и Ставрополье. В частности, по Краснодарскому краю актами ЧГК было зафиксировано уничтоже- ние 320 человек душевнобольных, находившихся на излечении в Краснодарской краевой психиатрической больнице, удушение газами 214 больных детей в детдоме г. Ейска, разрушение немцами в г. Тихорецке при отступлении городской и районной больниц, двух поликлиник и детских яслей и другие преступления. По Ставропольскому краю комиссия зафиксировала факт удушения в автомашинах-душегубках 660 пациентов Ставропольской психиатрической больницы, массовое уничтожение больных костным туберкулезом детей и сотрудников санаториев курорта Теберда Карачаевской автономной области, убийство врачей, медицинских сестер, обслуживающего персонала и пациентов ряда медицинских учреждений Кавказских Минеральных Вод и другие преступления [32]. Материалы ЧГК многократно публиковались в виде отдельных сообщений [48], сборников сообщений и актов [58], а также сборников сообщений, актов и отчетов об инициированных ЧГК судебных процессах [65].

Следует отметить, что, по мнению некоторых исследователей, на деятельность ЧГК могли оказывать влияние местные партийные организации и органы государственной безопасности [70]. Тем не менее, на протяжении всех прошедших после войны лет материалы ЧГК являются основой многочисленных отечественных и зарубежных исследований хода и последствий войны.

Еще одним видом источников являются архивные документы и материалы, включенные в различные сборники и опубликованные как центральными, так и краевыми издательствами Кубани [33] и Ставрополья [60], а также разнообразные статистические справочники [63]. Так, в одном из писем германского командования, опубликованном в сборнике документов «Преступные цели преступные средства», говорится о функционировании на территории оккупированных областей СССР фармацевтического акционерного общества с ограниченной ответственностью «Восток», задачей которого являлось снабжение восточных областей медикаментами и другими товарами употребляемыми в медицине и ветеринарии, а также предметами, необходимыми для врачей, ветеринаров, больниц и т.п. [52, с.356]

Большой объем материалов по указанной проблематике содержится в книгах сборника «Кубань в годы Великой Отечественной войны. 1941-1945 Рассекреченные документы. Хроника событий» $[40,41]$. В период своего пребывания на землях Кубани оккупанты разрушили 141 здание больниц и поликлиник, уничтожили более 60000 человек, насильственно угнали с территории края более 130000 человек, о чем составлено 13692 акта по установлению ущерба, представленных Краснодарской краевой комиссией в ЧГК. В краевом центре, вошедшем в число 10 самых пострадавших от оккупации городов, немцы уничтожили более 13000 человек, разрушили 9 больниц, 5 институтов, 20 детских яслей. В г. Армавире оккупанты расстреляли более 6680 граждан, В г. Кропоткине 2000, в станице Лабинской - более 2500 человек. 
Значительное количество материалов, описывающих повседневную жизнь населения Ставропольского края в период Великой Отечественной войны, в том числе и во время оккупации, содержится в сборнике документов «Голоса из провинции: жители Ставрополья в 1941-1964 годах» [4]. В сборнике «Ставрополье: правда военных лет. Великая Отечественная в документах и исследованиях» опубликованы материалы, касающиеся эвакуации народного хозяйства и жителей края накануне оккупации, подробностей жизни и быта населения в захваченном немцами регионе, обнародованы свидетельства о злодеяниях захватчиков, приведен ряд важных статистических данных. Существенная часть документов отражает проводимые советскими властями мероприятия по восстановлению мирной жизни после освобождения края от немецко-фрашистских захватчиков. Особо ценной для изучения рассматриваемой проблематики является докладная записка заведующего отделом здравоохранения Ставропольского крайисполкома Л. Я. Варшавского о мероприятиях по восстановлению лечебно-профилактической сети в крае № 157 от 22.02.1943 г [62, с. 286-291]. В данном документе довольно подробно описаны итоги пребывания немцев на территории края, которые, по мнению автора записки, выражались, прежде всего, в ликвидации и разграблении имущества всех межрайонных и районных санитарно-эпидемиологических, малярийных и туляремийных станций, закрытии медицинского института, бруцеллезной станции, санитарно-бактериологических лабораторий, повсеместном уничтожении запасов бакпрепаратов, отказе от проведения предохранительных прививок. Во-вторых, существенный урон понесла сеть лечебных учреждений края: значительное количество больниц было доведено до состояния полной невозможности их дальнейшего существования, закрыты краевая туберкулезная больница и тубдиспансер, разрушена республиканская психиатрическая больница, взорваны Ставропольский родильный дом и гинекологическое отделение городской больницы.

В сборнике документов “Ставрополье в период немецко-фрашистской оккупации (август 1942 январь 1943 гг.)» наряду с фрагментом статьи председателя ЧГК А. Н. Толстого «Коричневый дурман» приводится ряд документальных свидетельств о зверствах гитлеровцев в отношении жителей Ставрополя, городов Кавказских Минеральных Вод и других районов края. Размещенное в сборнике «Служебное указание №1 районным начальникам и городским головам», составленное германским командованием, содержит описание структуры районного управления, включающего в себя наряду с прочими подразделениями отдел здравоохранения или районного врача, в обязанности которого в первую очередь входило соблюдение санитарного состояния населения, наблюдение за работой аптек, бань и санпропускников [61].

Акты о злодеяниях оккупантов и учете убытков в Ставропольском медицинском институте и
Ставропольской краевой психиатрической больнице опубликованы в сборнике «Медицинский хронограф Ставрополья (1803-2016)» [43].

Еще одним видом источников, используемым при изучении исследуемого вопроса, является мемуарная литература. Несмотря на наличие субъективной составляющей, воспоминания переживших оккупацию людей предоставляют дополнительные сведения, которые при этом могут подтверждать или опровергать информацию из других источников. Примером такого вида источников является книга «Оккупация» Г. А. Беликова, представляющая собой воспоминания самого автора, а также многих других очевидцев оккупации г. Ставрополя [1]. В частности, автор, подтверждая закрытие Ставропольского медицинского института, приводит подробности, касающиеся судьбы некоторых преподавателей и студентов вуза, описывает работу городской больницы во время налета вражеской авиации и занятия немцами города. Немаловажными являются воспоминания автора о плохом санитарном состоянии города к концу периода оккупации, что подтверждает данные советских источников но противоречит версии оккупационных властей, указывавших в периодических изданиях на проведение ими всех необходимых мероприятий по приведению в порядок городских улиц, мест общего пользования и т.п.

Много информации, связанной с оккупацией г. Краснодара, содержит книга воспоминаний Ю. В. Ионова «Оккупация: до и после (записки старого краснодарского врача)" [38]. В частности, автор приводит подробности уничтожения оккупантами в машинах-«газвагенах» пациентов Краснодарской психиатрической больницы, расстрела жителей поселка Михизеева Поляна, описывает судьбы многих участников этих страшных событий, раскрывает детали повседневной жизни населения в захваченном городе.

Воспоминаниям о страшной трагедии, произошедшей в оккупированном г. Ейске, посвящена книга Л. В. Дворникова «От имени погибших» [31] Автор, чудом уцелевший воспитанник Ейского детского дома, описывает подробности жизни и трагической гибели 214 детей, умерщвленных оккупантами 9-10 октября 1942 г. Ценная информация, касающаяся оккупации г. Ставрополя и судьбе Ставропольского медицинского института в этот период времени, содержится в воспоминаниях А. А. Пильщикова [46, с. 130-135], В. Г. Кучмаевой $[46$, с. $103-108]$, Л. И. Виленского [46, с. 4145], Б. А. Полонского [45, с. 195-198] и В. С. Игропуло $[45$, с. $137-140]$.

Некоторые интересные детали содержатся в мемуарах немецкого офицера Э. Юнгера представляющих собой взгляд «с той стороны». В частности, автор, побывавший в конце 1942 начале 1943 гг. на Кубани и Ставрополье, упоминает о сделанной ему в г. Ставрополе прививке от сыпного тифра, рассказывает о посещении продолжавшего работу противочумного института $[69$, c. $225,231-232]$ 
Подводя итог обзору источниковой базы вопросов, связанных с политикой немецких властей в области здравоохранения, состоянием медицинского обслуживания населения, а также медико-санитарными последствиями пребывания оккупантов на территории Кубани и Ставрополья, необходимо отметить наличие значительного количества источников, описывающих причиненный захватчиками ущерб, выражавшийся в первую очередь в разрушении инфраструктуры и убийстве большого числа мирных жителей, включая врачей и пациентов лечебных учреждений. Для всестороннего изучения и объективного описания политики оккупационных властей в области здравоохранения, а также работы лечебно-профилактических учреждений на оккупированных территориях необходимо использовать максимальное количество различных по видам и информационной насыщенности исторических источников. Все они в своей совокупности позволят более детально рассмотреть и раскрыть тему функционирования системы здравоохранения на оккупированных территориях Краснодарского и Ставропольского краев в период 1942-1943 годов.

\section{Источники и литература}

1. Беликов Г.А. Оккупация. Ставрополь: Фонд духовного просвещения, 1998. 151 с.

2. Бешеные волки // Красная Звезда. 1943. 15 июля.

3. Врачебные участки // Кубань. 1942. 6 октября.

4. Голоса из провинции: жители Ставрополья в 1941-1964 годах (Сборник документов) / составители В. В. Белоконь, Т. Н. Колпикова, Г. А. Никитенко. Ставрополь: Комитет Ставропольского края по делам архивов, 2011.696 с.

5. Городская жизнь // Русская правда. 1942. 11 августа.

6. Городская жизнь // Русская правда. 1942. 15 августа.

7. Городская жизнь // Ставропольское слово. 1942. 16 сентября.

8. Государственный архив Краснодарского края (далее - ГАКК). Ф.Р - 418. Оп.1. Д.1, 2, 5 - 12, 16, 17.

9. ГАКК. Ф.Р-430. ОП.1. Д.24.

10. ГАКК. Ф.Р-440. ОП.1. Д.3, 7, 9.

11. ГАКК. Ф.Р-477. ОП.1. Д.1.

12. ГАКК. Ф.Р-505. ОП.1. Д. 4.

13. ГАКК. Ф.Р-584. ОП.1. Д.1

14. ГАКК. Ф.Р-590. ОП.1. Д.1.

15. ГАКК. Ф.Р-897. ОП.1. Д.1-33

16. ГАКК. Ф.Р-1255. ОП.1. Д.24.

17. ГАКК. Ф.Р-1393. Оп.1. Д.1.

18. Государственный архив новейшей истории Ставропольского края (далее - ГАНИСК). Ф.1. Оп.2. Д.92.

19. ГАНИСК. Ф.23. Оп.1. Д.1069.

20. Государственный архив Российской Федерации (далее - ГАРФ). Ф.Р-7021. Оп.16. Д.1-587.

21. ГАРФ. Ф.Р-7021. Оп.17. Д.1-311.

22. ГАРФ. Ф.Р-7445. Оп.2. Д.99. Л.188, 194, 239.

23. Государственный архив Ставропольского края (далее - ГАСК). Ф.Р-1053. Оп.1. Д.1, 6, 31-33, 41, 73, 116.

24. ГАСК. Ф.Р-1059. ОП.1. Д.8.

25. ГАСК. Ф.Р-1121. ОП.1. Д.5.

26. ГАСК. Ф.Р-1368. ОП.1. Д.1-285.

27. ГАСК. Ф.Р-2498. ОП.1. Д.27, 29.

28. ГАСК. Ф.Р-2569. ОП.1. Д.9, 10.

29. Грабежи и насилия оккупантов на Кубани // Большевик. 1942. 16 сентября.

30. Детская поликлиника // Русская правда. 1942. 12 августа.

31. Дворников Л. В. От имени погибших: документальная повесть. Краснодар: Периодика Кубани, 2016. 352 с.

32. Документы обвиняют. Сборник документов о чудовищных преступлениях немецко-фашистских захватчиков на советской территории. Выпуск 2. М.: Госполитиздат, 1945. 391 с.

33. Документы отваги и героизма. Кубань в Великой Отечественной войне 1941-1945 гг. Краснодар: Кн. изд-во, 1965. $296 \mathrm{C}$.

34. Доронина Н. В. Нацистская пропаганда на оккупированных территориях Ставрополья и Кубани в 1942-1943 гг:: цели, особенности, крах: Дис. ... канд. ист. наук. Ставрополь, 2005. 181 с.

35. Жизнь в Пятигорске // Утро Кавказа. 1942. 16 декабря

36. Заботы о здоровье населения // Утро Кавказа. 1943. 1 января.

37. Здравоохранение в крае // Утро Кавказа. 1942. 13 декабря.

38. Ионов Ю. В. Оккупация: до и после (записки старого краснодарского врача). Краснодар: Экоинвест, 2014. 213 с

39. Кононенко Е. В. Перед судом народа // Большевик. 1943. 16 июля.

40. Кубань в годы Великой Отечественной войны. 1941-1945: Рассекреченные документы. Хроника событий: 19411942 гг. Краснодар: Сов. Кубань, 2000. 816 с.

41. Кубань в годы Великой Отечественной войны. 1941-1945: Рассекреченные документы. Хроника событий: 1943 г. Краснодар: Сов. Кубань, 2003. 896 с.

42. Линец С. И. Северный Кавказ накануне и в период немецко-фашистской оккупации: состояние и особенности развития (июль 1942 - октябрь 1943 гг.). Ростов н/Д: Изд-во СКНЦ ВШ, 2003. 564 с.

43. Медицинский хронограф Ставрополья: Сборник исторических материалов / сост. А. В. Карташев, А. К. Курьянов. Ставрополь: Изд-во СтГМУ, 2016. 256 с. 
44. Медицинское обслуживание населения // Кубань. 1942. 26 сентября.

45. Мир Кавказу: общая Память - общая Судьба // Материалы Ставропольской городской научно-практической конференции. Ставрополь: СтГМА, 2011. 283 с.

46. На рубежах Кавказа: сборник докладов, выступлений, научных статей по материалам научно-практических конференций СтГМА, посвященных 65-й годовщине Победы в Великой Отечественной войне. Ставрополь: СтГМА, 2010. 194 c.

47. Наш бюджет // Ставропольское слово. 1942. 2 сентября.

48. О злодеяниях немецко-фашистских оккупантов в Ставропольском крае. М.: Госполитиздат, $1943.29 \mathrm{c}$

49. Объявления // Ставропольское слово. 1942. 11 сентября.

50. Объявление // Утро Кавказа. 1943. 3 января.

51. По следам фашистского зверя // Большевик. 1942. 9 октября.

52. Преступные цели - преступные средства. Документы об оккупационной политике фашистской Германии на территории СССР. (1941-1944 гг.). М.: Политиздат, 1968. 383 с.

53. При болезни зарплата сохраняется // Ставропольское слово. 1942. 16 октября.

54. Привести город в образцовое санитарное состояние (Совещание медицинских работников г. Ставрополя) // Ставропольская правда. 1943. 16 февраля.

55. Приказ Бургомистра // Кубань. 1942. 1 ноября.

56. Приказ Городского Управления // Ставропольское слово. 1942. 20 сентября

57. Приказы и распоряжения // Русская правда. 1942. 4 августа.

58. Сборник сообщений Чрезвычайной Государственной Комиссии о злодеяниях немецко-фашистских захватчиков. М.: Госполитиздат, 1946. 476 с.

59. Сообщение Чрезвычайной государственной комиссии о злодеяниях немецко-фашистских захватчиков в Краснодаре и Краснодарском крае // Большевик. 1943. 13 июля.

60. Ставрополье в Великой Отечественной войне 1941-1945 гг. Сборник документов и материалов. - Ставрополь: Кн. изд-во, 1962. 515 с.

61. Ставрополье в период немецко-фашистской оккупации (август 1942 - январь 1943 гг.): документы и материалы / Сост. В. А. Водолажская, М. И. Кривнева, Н. И. Мельник. Ставрополь: Кн. изд-во, 2000. 175 с.

62. Ставрополье: правда военных лет. Великая Отечественная в документах и исследованиях / Науч. ред. проф.

Т. А. Булыгина; Сост.: В. В. Белоконь, Т. Н. Колпикова, Я. Г. Кольцова, В. Л. Мазница. Ставрополь: Изд-во СГУ, 2005.608 с. 63. Страна Советов за 50 лет. Сборник статистических материалов. М., Статистика, 1967. 352 с

64. Судебный процесс по делу о зверствах немецко-фашистских захватчиков и их пособников на территории гор. Краснодара и Краснодарского края в период их временной оккупации // Комсомольская правда. 1943.18 июля.

65. Судебный процесс по делу о зверствах немецко-фашистских захватчиков и их пособников на территории гор. Краснодара и Краснодарского края в период их временной оккупации. М. : Госполитиздат, 1943.48 с.

66. Такса по зубной поликлинике // Кубань. 1942. 14 ноября.

67. Центр документации новейшей истории Краснодарского края. Ф.1774-А.Оп.2. Д.391.

68. Чудовищные зверства фашистских палачей на Кубани // Большевик. 1942. 24 ноября.

69. Юнгер Э. Излучения (февраль 1941 - апрель 1945) / Перевод с немецкого Н.О. Гучинской, В.Г. Ноткиной. СПб.: Владимир Даль, 2002. 784 с.

70. Dieter Pohl. Die einheimischen Forschungen und der Mord an Juden in den besetzten Gebieten. S. $206 /$ In: Wolf Kaiser. Tater im Vernichtungskrieg. Berlin, 2002. S. 204-216

\section{References}

1. Belikov G. A. Okkupatsiya (Occupation). Stavropol: Fond dukhovnogo prosveshcheniya, 1998.151 p. (In Russian).

2. Beshenye volki (Rabid Wolves) // Krasnaya zvezda. 1943. July 15. (In Russian).

3. Vrachebnye uchastki (Medical Areas) // Kuban'. 1942. October 6. (In Russian).

4. Golosa iz provincii: zhiteli Stavropol'ya v 1941-1964 godah (Sbornik dokumentov) (Voices from the Province: Stavropol

Residents in 1941-1964 (Collection of Documents). Stavropol': Komitet Stavropol'skogo kraya po delam arhivov, 2011.696 p. (In Russian)

5. Gorodskaya zhizn' (City Life) // Russkaya pravda. 1942. August 21. (In Russian).

6. Gorodskaya zhizn' (City Life) // Russkaya pravda. 1942. August 15. (In Russian).

7. Gorodskaya zhizn' (City Life) // Stavropol'skoe slovo. 1942. September 16. (In Russian).

8. Gosudarstvennyj arhiv Krasnodarskogo kraya (GAKK). F.R-418. Inv.1. D.1, 2, 5-12, 16, 17. (In Russian).

9. GAKK. F.R-430. Inv.1. D.24. (In Russian).

10. GAKK. F.R-440. Inv.1. D. 3, 7, 9. (In Russian)

11. GAKK. F.R-477. Inv.1. D.1. (In Russian)

12. GAKK. F.R-505. Inv.1. D.4. (In Russian)

13. GAKK. F.R-584. Inv.1. D.1. (In Russian)

14. GAKK. F.R-590. Inv.1. D.1. (In Russian)

15. GAKK. F.R-897. Inv.1. D.1 - 33. (In Russian)

16. GAKK. F.R-1255. Inv.1. D.24. (In Russian).

17. GAKK. F.R-1393. Op.1. D.1. (In Russian).

18. Gosudarstvennyj arhiv novejshej istorii Stavropol'skogo kraya (GANISK). F.1. Inv.2. D.92. (In Russian).

19. GANISK. F.23. Inv.1. D.1069. (In Russian).

20. Gosudarstvennyj arhiv Rossijskoj Federacii (GARF). F. R-7021. Op. 16. D. 1-587. (In Russian).

21. GARF. F.R-7021. Inv.17. D.1-311. (In Russian). 
22. GARF. F. R-7445. Inv.2. D.99. L. 188, 194, 239. (In Russian).

23. Gosudarstvennyj arhiv Stavropol'skogo kraya (GASK). F.R-1053. Inv.1. D.1, 6, 31-33, 41, 73, 116. (In Russian).

24. GASK. F.R-1059. Inv.1. D.8. (In Russian).

25. GASK. F.R-1121. Inv.1. D.5. (In Russian).

26. GASK. F.R-1368. Inv.1. D.1-285. (In Russian)

27. GASK. F.R-2498. Inv.1. D.27, 29. (In Russian)

28. GASK. F.R-2569. Inv.1. D.9, 10. (In Russian).

29. Grabezhi i nasiliya okkupantov na Kubani (The Looting and Violence of the Occupiers of the Kuban) // Bol'shevik. 1942. September 16. (In Russian).

30. Detskaya poliklinika (Children's Clinic) // Russkaya pravda. 1942. August 12. (In Russian).

31. Dvornikov L. V. Ot imeni pogibshih: dokumental'naya povest' (On Behalf of the Dead: a Documentary Story). Krasnodar: Periodika Kubani, 2016. 352 p. (In Russian).

32. Dokumenty obvinyayut. Sbornik dokumentov o chudovishchnyh prestupleniyah nemecko-fashistskih zahvatchikov na sovetskoj territorii (The Documents Accuse. A Collection of Documents about the Monstrous Crimes of the German Fascist Invaders on Soviet Ternitory). Issue 2. Moscow: Gospolitizdat, 1945. 391 p. (In Russian).

33. Dokumenty otvagi i geroizma. Kuban' v Velikoj Otechestvennoj vojne 1941-1945 gg. (Documents of courage and heroism. Kuban in the great Patriotic war of 1941-1945). Krasnodar: Kn. izd-vo, 1965. 296 p. (In Russian).

34. Doronina N. V. Nacistskaya propaganda na okkupirovannyh territoriyah Stavropol'ya i Kubani v 1942-1943 gg.: celi, osobennosti, krah (Nazi propaganda in the occupied territories of Stavropol and Kuban in 1942-1943.: goals, features, collapse): thesis. Stavropol', 2005. 181 p. (In Russian).

35. Zhizn' v Pyatigorske (Life in Pyatigorsk) // Utro Kavkaza. 1942. Desember 16. (In Russian)

36. Zaboty o zdorov'e naseleniya (Worries about the health of the population) // Utro Kavkaza. 1943. January 1. (In Russian).

37. Zdravoohranenie $v$ krae (Health care in the region) // Utro Kavkaza. 1942. Desmber 13. (In Russian)

38. Ionov Y. V. Okkupaciya: do i posle (zapiski starogo krasnodarskogo vracha) (The Occupation: before and after (notes of the old Krasnodar physician). Krasnodar: Ekoinvest, 2014. 213 p. (In Russian).

39. Kononenko E. V. Pered sudom naroda (Before the court of the people) // Bol'shevik. 1943. July 16. (In Russian).

40. Kuban' v gody Velikoj Otechestvennoj vojny. 1941-1945: Rassekrechennye dokumenty. Hronika sobytij: 1941-1942 gg. (Kuban during the Great Patriotic War. 1941-1945: Declassified documents. Chronicle of events: 1941-1942). Krasnodar: Sov. Kuban', 2000. 816 p. (In Russian).

41. Kuban' v gody Velikoj Otechestvennoj vojny. 1941-1945: Rassekrechennye dokumenty. Hronika sobytij: $1943 \mathrm{~g}$ (Kuban during the Great Patriotic War. 1941-1945: Declassified documents. Chronicle of events: 1943). Krasnodar: Sov Kuban', 2003. 896 p. (In Russian).

42. Linec S. I. Severnyj Kavkaz nakanune i v period nemecko-fashistskoj okkupacii: sostoyanie i osobennosti razvitiya (iyul' 1942 - oktyabr' $1943 \mathrm{gg}$.) (The North Caucasus before and during the Nazi occupation: the Status and features of development, July 1942 - October 1943). Rostov on Don: SKNC VSH publ., 2003. 564 p. (In Russian).

43. Medicinskij hronograf Stavropol'ya: Sbornik istoricheskih materialov (Medical chronograph Stavropol: Collection of historical materials) / sost. A.V. Kartashev, A.K. Kur'yanov. Stavropol': StGMU publ., 2016. 256 p. (In Russian)

44. Medicinskoe obsluzhivanie naseleniya (Health services) // Kuban'. 1942. September 26. (In Russian).

45. Mir Kavkazu: obshchaya Pamyat' - obshchaya Sud'ba (Peace to the Caucasus: common Memory - common Destiny) // Materialy Stavropol'skoj gorodskoj nauchno-prakticheskoj konferencii. Stavropol': StSMA publ., 2011. 283 p. (In Russian).

46. Na rubezhah Kavkaza: sbornik dokladov, vystuplenij, nauchnyh statej po materialam nauchno-prakticheskih konferencij StGMA, posvyashchennyh 65-j godovshchine Pobedy v Velikoj Otechestvennoj vojne (On the borders of the Caucasus: a collection of reports, speeches, scientific articles on the materials of scientific conferences StGMA dedicated to the 65th anniversary of victory in the Great Patriotic War). Stavropol': StSMA publ., 2010. 194 p. (In Russian).

47. Nash byudzhet (Our budget) // Stavropol'skoe slovo. 1942. September 2. (In Russian).

48. O zlodeyaniyah nemecko-fashistskih okkupantov $\vee$ Stavropol'skom krae (About the atrocities of the Nazi occupiers in the Stavropol region). Moscow: Gospolitizdat, 1943. 29 p. (In Russian).

49. Ob»yavleniya (Announcement) // Stavropol'skoe slovo. 1942. September 11. (In Russian).

50. Ob»yavlenie (Announcement) // Utro Kavkaza. 1943. January 3. (In Russian).

51. Po sledam fashistskogo zverya (In the footsteps of a fascist beast) // Bol'shevik. 1942. October 9. (In Russian).

52. Prestupnye celi - prestupnye sredstva. Dokumenty ob okkupacionnoj politike fashistskoj Germanii na territorii SSSR. (1941-1944 gg.) (Criminal targets are criminal means. Documents on the occupation policy of Nazi Germany in the USSR. (1941-1944). Moscow: Politizdat, 1968. 383 p. (In Russian).

53. Pri bolezni zarplata sohranyaetsya (Under disease wages reduce) // Stavropol'skoe slovo. 1942. October 16. (In Russian).

54. Privesti gorod v obrazcovoe sanitarnoe sostoyanie (Soveshchanie medicinskih rabotnikov g. Stavropolya) (To bring the city to an exemplary sanitary condition (Meeting of medical workers of Stavropol) // Stavropol'skaya pravda. 1943. February 16. (In Russian).

55. Prikaz Burgomistra (Order Of The Burgomaster) // Kuban'. 1942. November 1. (In Russian).

56. Prikaz Gorodskogo Upravleniya (Order of the City Administration) // Stavropol'skoe slovo. 1942. September 20. (In Russian).

57. Prikazy i rasporyazheniya (Orders) // Russkaya pravda. 1942. August 4. (In Russian).

58. Sbornik soobshchenij Chrezvychajnoj Gosudarstvennoj Komissii o zlodeyaniyah nemecko-fashistskih zahvatchikov (Collection of reports of the Emergency state Commission on the atrocities of the Nazi invaders). Moscow: Gospolitizdat, 1946. 476 p. (In Russian). 
59. Soobshchenie Chrezvychajnoj gosudarstvennoj komissii o zlodeyaniyah nemecko-fashistskih zahvatchikov v Krasnodare i Krasnodarskom krae (The message of the Extraordinary state Commission on atrocities of the German fascist invaders in Krasnodar and the Krasnodar region) // Bol'shevik. 1943. July 13. (In Russian).

60. Stavropol'e v Velikoj Otechestvennoj vojne 1941-1945 gg. Sbornik dokumentov i materialov (Stavropol in the great Patriotic war of 1941-1945. Collection of documents and materials). Stavropol': Kn. izd-vo, 1962. 515 p. (In Russian).

61. Stavropol'e v period nemecko-fashistskoj okkupacii (avgust 1942 - yanvar' 1943 gg.): dokumenty i materialy (Stavropol region during the Nazi occupation (August 1942 - January 1943): documents and materials). Stavropol': Kn. izd-vo, 2000. 175 p. (In Russian).

62. Stavropol'e: pravda voennyh let. Velikaya Otechestvennaya v dokumentah i issledovaniyah (Stavropol: the truth of the war years. The Great Patriotic War in documents and research). Stavropol': SSU publ., 2005. 608 p. (In Russian).

63. Strana Sovetov za 50 let. Sbornik statisticheskih materialov (Country of the Soviets over 50 years. Collection of statistical materials). Moscow: Statistika, 1967. 352 p. (In Russian).

64. Sudebnyj process po delu o zverstvah nemecko-fashistskih zahvatchikov i ih posobnikov na territorii gor. Krasnodara i Krasnodarskogo kraya $v$ period ih vremennoj okkupacii (The trial of the atrocities of the Nazi invaders and their accomplices in the mountains. Krasnodar and the Krasnodar ternitory in the period of their temporary occupation) // Komsomol'skaya pravda 1943. July 18. (In Russian).

65. Sudebnyj process po delu o zverstvah nemecko-fashistskih zahvatchikov i ih posobnikov na territorii gor. Krasnodara i Krasnodarskogo kraya v period ih vremennoj okkupacii (The trial of the atrocities of the Nazi invaders and their accomplices in the mountains. Krasnodar and the Krasnodar ternitory in the period of their temporary occupation). Moscow: Gospolitizdat 1943. 48 p. (In Russian)

66. Taksa po zubnoj poliklinike (Tax on dental clinic) // Kuban'. 1942. November 14. (In Russian).

67. Centr dokumentacii novejshej istorii Krasnodarskogo kraya. F.1774-A. Inv.2. D.391. (In Russian).

68. Chudovishchnye zverstva fashistskih palachej na Kubani (The monstrous atrocities of the Nazi executioners in the Kuban) // Bol'shevik. 1942. November 24. (In Russian).

69. Yunger E. Izlucheniya (fevral' 1941 - aprel' 1945) (Emissions). St.Petersburg: Vladimir Dal', 2002.784 p. (In Russian).

70. Dieter Pohl. Die einheimischen Forschungen und der Mord an Juden in den besetzten Gebieten (The local research and the murder of Jews in the occupied territories). S. 206 / In: Wolf Kaiser. Tater im Vernichtungskrieg. Berlin, 2002. S. 204216. (In Russian).

\section{Информация об авторе}

Карташев Игорь Владимирович - младший научный сотрудник центра изучения истории медицины Ставропольский государственный медицинский университет (Ставрополь) / kartashev_iv@mail.ru

\section{Information about the author}

Kartashev Igor - junior research fellow, Center for Study of Medicine History, Stavropol State Medical University (Stavropol) / kartashev_iv@mail.ru 